\title{
The Attributes of Concrete Produced by using of Aljufra and Sirte Aggregate
}

\author{
Ahmed Mohmed Ahmed Blash ${ }^{1}$, Hussein Mohmed Hussein Ahmeed ${ }^{2}$ \\ ${ }^{1}$ Department of Civil Engineering, Acharya Nagarjuna University, Guntur, Andhra Pradesh, India \\ ${ }^{2}$ Department Civil Engineering Higher Institute of Sciences and Technology -Aljufra, Sokna-Libya
}

\begin{abstract}
This study was to know some of the mechanical characteristics of the two types of aggregate at different rates used in the central region in Libya (the aggregate of the Sirte limestone, Ruins of volcanic Aljufra) impact on resisting pressure and concrete floats after testing available led the research results to the following conclusion: Knowledge of the mechanical characteristics of the aggregate help in determining the validity of the use of the most suitable places for use and the results indicate that the aggregate of Aljufra is mechanical properties best in terms of the percentage of low absorption compared to the Sandbank Sirte containing the pores more than weaken its resistance to pressure the stretching, also Aljufra aggregate gave the highest results from shock hand land resistance is therefore more appropriately mixture prone to crash land concrete factories, warehouses and roads. It is during the tests results gave the samples containing the ruins of Aljufra more resistant to pressure from the samples containing the aggregate of the Sirte this can be explained by the fact that the aggregate of the Sirte contains pores more which affected the quantity of water to Hydration of cement. The results showed also that concrete with sandbank Aljufra more resistant tensile strength of the samples containing the ruins of Sirte, this can be ascribed to the surface roughness wreck Aljufra compared sandbank Sirte. It is during the tests results gave the samples containing the aggregate by $16 \%$ more resistant to pressure the stretching of samples containing the ruins of $32 \%$ of the amalgam concrete blocks which is expected the lack of article predators known as hyaenodontids between particles of aggregate.
\end{abstract}

Keywords: Aggregate, quarries, Sirte, Aljufra, Libya

\section{Introduction}

Is the natural wealth around the world is one of the basic pillars underlying any state in the areas of development, and that is why it is important to develop ways to remove it and marketing properly. In Libya, it is expected that the State is witnessing rapid growth in the construction sector and industry facilities in the next few years. Where there is an urgent need to compensate the physical recession throughout the last decades, especially in the sector of residential buildings. This development necessary to meet the requirements of the market in sufficient quantities of construction materials of quality, performance and timely manner to accommodate this urbanization hoped. On top of these requirements come rock resources (aggregate) available in huge quantities in Libya.

The quality and characteristics of the rough aggregate and soft-toned has a great effect on the behaviour of the concrete situation in the Committee and solid because it holds $\mathbf{7 5}$ percent of the total size of the concrete. Where the aggregate is of the utmost importance and is responsible for determining the power and performance of durability concrete and improve the operating feature and resist the tension arm and pressure. That is why the trend to study the best kinds of rough aggregate we have available to avoid the use of the pile of coarse quality less.

\section{Objective}

The present paper is to identify and compare the attributes of the aggregate from two different sources (a quarry at Sirte limestone-quarry volcanic Aljufra) and the impact of this on the quality of the hard concrete for concrete high-resistance and match the specifications by using more than one source earth tumults and its addendum at different rates mix concrete.

\section{The materials used}

\subsection{Water}

The use of drinking water net free from the impurities for the purpose of mixing and address concrete samples.

\subsection{Cement}

Use normal portland cement commonly used and the product locally within the Libyan specifications. Test the softness of cement using save No. 200, the proportion was reserved for 19.1\%, which coincides with US specifications ASTM C 150

\subsection{Fine Sand}

In this study used the sedimentary natural sand brought from Wadan city for its quality and high resistance to give it the sand after 28 day of casting. Table 1 shows the save analysis.

Table 1: Save analysis of Fine Sand

\begin{tabular}{|c|c|}
\hline Save $N O(\mathrm{~mm})$ & Passing 20-37 (\%) \\
\hline 2.5 & 99.84 \\
\hline 1.25 & 99.67 \\
\hline 0.63 & 99.23 \\
\hline 0.31 & 44.835 \\
\hline 0.16 & 26.35 \\
\hline Pan & 8.8 \\
\hline
\end{tabular}

\subsection{Aggregate}




\section{International Journal of Science and Research (IJSR) \\ ISSN (Online): 2319-7064}

Index Copernicus Value (2013): 6.14 | Impact Factor (2015): 6.391

Aggregate used in this search is from two sources (a quarry at Sirte limestone and quarry volcanic Aljufra).

\section{Concrete mixture}

To maintains the quality of aggregate, tested samples of aggregate different source to inspect of the physical characteristics, mechanical characteristics and comparison of frontiers in specifications. Then was the preparation of the two types of concrete mixtures of each type of rough aggregate according to the source of the aggregate of the user has been named mixtures according to the type of aggregate user rough.

It is these mixtures was poured 24 cubes of concrete by size ( $150 \mathrm{~mm} \times 150 \mathrm{~mm} \times 150 \mathrm{~mm}$ ) to test the resistance pressure [4], as well as have been pouring 24 concrete cylinder $(150 \mathrm{~mm} \times 300 \mathrm{~mm})$ to test the resistance of the tension in the others [5]. Mixed samples then poured concrete at three layers and vibrated by vibration mechanical for 10 seconds each layer. Then, only rooftop terrace and left samples in the air inside the lab one day, after the templates and flooded the cubes and drums in the water for 7 and 28 on for the purpose of treatment. Table 2 shows the concrete mixtures of the subject of the study.

Table 2: Concrete mixtures Used

\begin{tabular}{|c|c|c|c|c|c|}
\hline \multirow{2}{*}{ Sample } & \multirow{2}{*}{ Cement } & \multirow{2}{*}{ Sand } & \multicolumn{2}{|c|}{ Aggregate } & \multirow{2}{*}{ W/C \% } \\
\cline { 4 - 6 } & & & Aljufra & Sirte & \\
\hline Sirte (standard) & 1 & 2 & 0 & 2.5 & 0.65 \\
\hline Sirte (16\%) & 1 & 2 & 0 & 2.9 & 0.65 \\
\hline Sirte (32\%) & 1 & 2 & 0 & 3.3 & 0.65 \\
\hline Aljufra (standard) & 1 & 2 & 2.5 & 0 & 0.65 \\
\hline Aljufra (16\%) & 1 & 2 & 2.9 & 0 & 0.65 \\
\hline Aljufra (32\%) & 1 & 2 & 3.3 & 0 & 0.65 \\
\hline
\end{tabular}

\section{Results and Discussion}

\subsection{Tests of Aggregate}

Table 3 shows the result of mechanical tests of aggregate samples.

Table 3: Mechanical Tests of Aggregate

\begin{tabular}{|c|c|c|c|c|}
\hline \multirow{2}{*}{ The Type of Testing } & \multicolumn{2}{|c|}{ Aggregate } & \multirow{2}{*}{ Limit } & \multirow{2}{*}{ Specifications } \\
\hline & Sirte & Aljufra & & \\
\hline $\begin{array}{c}\text { Specific Absorption } \\
\text { Rate } \%\end{array}$ & 1.97 & 1.3 & $\begin{array}{l}\text { Less than } \\
2 \%\end{array}$ & $\begin{array}{c}A S T M \text { C128/ } \\
C 127[6,7]\end{array}$ \\
\hline Qualitative weight & 2.5 & 2.69 & $\begin{array}{l}\text { Greater } \\
\text { than } 2.6\end{array}$ & $\begin{array}{c}A S T M \text { C128/ } \\
C 127[6,7]\end{array}$ \\
\hline Los Angeles \% & 20 & 17.8 & $\begin{array}{l}\text { No more } \\
\text { than } 30 \%\end{array}$ & $\begin{array}{c}\text { ASTM C131/C } \\
535[8,9]\end{array}$ \\
\hline Collision Factor \% & 35 & 27 & $\begin{array}{l}\text { No more } \\
\text { than } 30 \%\end{array}$ & $\begin{array}{c}\text { BS } 812 \text { Part 2: } \\
112 \text { [10] }\end{array}$ \\
\hline $\begin{array}{c}\text { Coefficient of } \\
\text { Crushing \% }\end{array}$ & 22.9 & 17.8 & $\begin{array}{c}\text { No more } \\
\text { than } 45\end{array}$ & $\begin{array}{c}\text { BS 812 Part 2: } \\
110\end{array}$ \\
\hline
\end{tabular}

- Specific absorption rate and qualitative weight test: The result has shown that the proportion of water sink Sirte aggregate is higher than Aljufra aggregate. But it remained both types of aggregate within specifications as indicated in the Table 3. Also, weight values qualitative development of two types of aggregate within the American specifications. In other words, can be summarized that the Aljufra aggregate heavier than Sirte aggregate porous and absorb less.

- Los angeles test: Collision factor and Coefficient of crushing test qualitative remained the aggregate within specifications collision transactions, boomerangs and resist the road. The results indicate that the aggregate of Aljufra more solid and the most suitable for use in concrete prestressing and which are subjected to the severest such as friction and erosion. The result as shown in Table 3.

\section{- Microscopic examination results:}

1) The regular Lens: In both cases the aggregate is uneven and many corners which needs to water and cement and more. The aggregate of the Sirte rooftop smoother and more of aggregate Aljufra which reduces the amount of water required concrete mix.
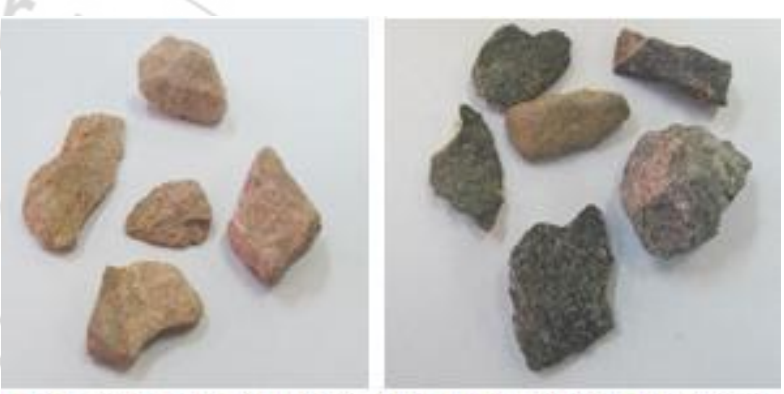

Figure 1: Sirt aggregate. Figure 2: Aljufra aggregate

2) Zoom lens 10x: The exterior surface of the Sirte aggregate unlike the aggregate of Aljufra. So, Many vents at the surface of the Sirte aggregate more than Aljufra aggregate. These sediments and vent may operate as tier buffer between the aggregate and cement in the fresh concrete which may affect the quality of the concrete.

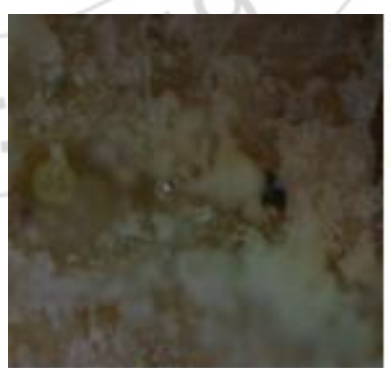

Figure 3: Sirt aggregate $(10 \mathrm{x})$.

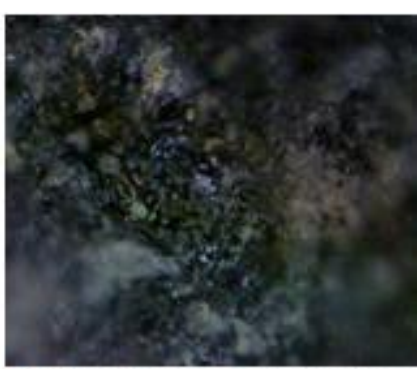

Figure 4: Aljufra aggregate $(10 \mathrm{x})$
3) Zoom lens 20x: The aggregate of the Sirte features a blend of colors representing many constituent metals rocks mother during sedimentation. The aggregate of Aljufra black colour bold resulting from the volcanic rocks. 


\section{International Journal of Science and Research (IJSR) \\ ISSN (Online): 2319-7064}

Index Copernicus Value (2013): 6.14 $\mid$ Impact Factor (2015): 6.391

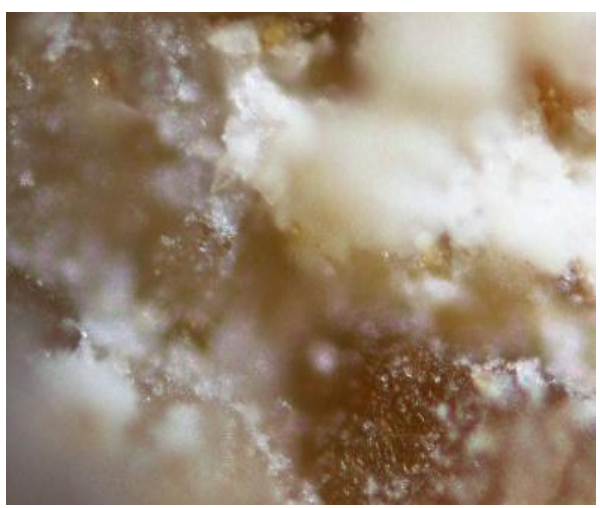

Figure 5: Sirt aggregate (20x)

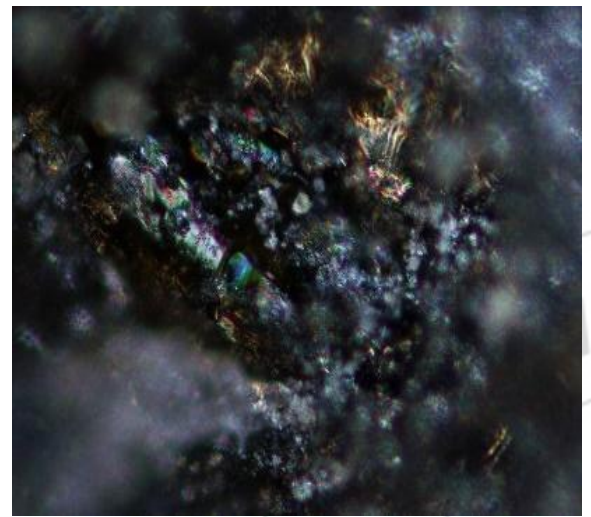

Figure 6: Aljufra aggregate (20x)

4) Slump Test: Table 4 shows the results of slump test fresh concrete incarnated samples aggregate (Sirte, Aljufra). Given productive mixtures using the aggregate of the Sirte less fall. Perhaps this explains the proportion of high suction Sirte aggregate if compared by Aljufra aggregate. But the rest of All mixtures within the flaccid strength and did not affect significantly the characteristics of the landing mix fresh concrete.

Table 4: Slump test of fresh concrete

\begin{tabular}{|c|c|c|c|}
\hline Sample & $\begin{array}{c}\text { oaggregate } \\
\text { of Sirte } \\
(\mathrm{mm})\end{array}$ & $\begin{array}{c}\text { Aljufra } \\
\text { aggregate } \\
(\mathrm{mm})\end{array}$ & $\begin{array}{c}\text { The proportion of } \\
\text { the difference in } \\
\text { landing (\%) }\end{array}$ \\
\hline Standard & 95 & 100 & 5.0 \\
\hline $16 \%$ aggregate & 90 & 90 & 0.0 \\
\hline $32 \%$ aggregate & 88 & 95 & 7.4 \\
\hline
\end{tabular}

\section{Hardened concrete tests}

\subsection{Compressive test}

This includes the results of the tests of resisting pressure of the samples containing the aggregate of Sirte and Aljufra aggregate after curing water at the age of 7 and 28 days. In general, the results indicate that the resistance of the pressure in Table 5, the samples containing the aggregate of Aljufra is higher than Sirte aggregate.

Also, the results proved that the rate increased in resisting pressure in cubes that contain $32 \%$ from Aljufra aggregate in concrete mixture less than cubes containing of $16 \%$. On the other hand,the result of the concrete containing Sirte aggregate there is not too much defferent between $32 \%$ and
$16 \%$.

Table 5: Result of Compressive Test

\begin{tabular}{|c|c|c|c|}
\hline Sample & $\begin{array}{c}\text { Age } \\
\text { (Day) }\end{array}$ & $\begin{array}{l}\text { average } \\
(\mathrm{N} / \mathrm{mm} 2)\end{array}$ & $\begin{array}{l}\text { The rate of increase in } \\
\text { resisting pressure from } \\
\text { age } 7 \text { to age } 28 \text { on }\end{array}$ \\
\hline \multirow{2}{*}{ Sirte (standard) } & 7 & 21.64 & \multirow{2}{*}{$29.07 \%$} \\
\hline & 28 & 30.52 & \\
\hline \multirow{2}{*}{ Sirte $(16 \%)$} & 7 & 27.63 & \multirow{2}{*}{$12.26 \%$} \\
\hline & 28 & 31.49 & \\
\hline \multirow{2}{*}{ Sirte $(32 \%)$} & 7 & 27.35 & \multirow{2}{*}{$12.09 \%$} \\
\hline & 28 & 31.11 & \\
\hline \multirow{2}{*}{ Aljufra (standard) } & 7 & 31.29 & \multirow{2}{*}{$13.61 \%$} \\
\hline & 28 & 36.22 & \\
\hline \multirow{2}{*}{ Aljufra (16\%) } & 7 & 41.93 & \multirow{2}{*}{$3.61 \%$} \\
\hline & 28 & 43.5 & \\
\hline \multirow{2}{*}{ Aljufra $(32 \%)$} & 7 & 32.32 & \multirow{2}{*}{$95.7 \%$} \\
\hline & 28 & 35.11 & \\
\hline
\end{tabular}

\subsection{Test the tensile strength of indirect}

This resistance of concrete tensile strength of the samples containing the aggregate of Sirte and Aljufra aggregate after curing water at the age of 7 and 28 days. Tble 6 showes the result of the test.

Table 6: Result of Tension Test

\begin{tabular}{|c|c|c|c|}
\hline Sample & $\begin{array}{c}\text { Age } \\
\text { (Day) }\end{array}$ & $\begin{array}{l}\text { average } \\
(\mathrm{N} / \mathrm{mm} 2)\end{array}$ & $\begin{array}{l}\text { The rate of increase in } \\
\text { resisting pressure from } \\
\text { age } 7 \text { to age } 28 \text { on }\end{array}$ \\
\hline \multirow{2}{*}{ Sirte (standard) } & 7 & 1.59 & \multirow{2}{*}{$35.37 \%$} \\
\hline & 28 & 2.46 & \\
\hline \multirow{2}{*}{ Sirte $(16 \%)$} & 7 & 1.67 & \multirow{2}{*}{$11.17 \%$} \\
\hline & 28 & 1.88 & \\
\hline \multirow{2}{*}{ Sirte $(32 \%)$} & 7 & 1.52 & \multirow{2}{*}{$12.09 \%$} \\
\hline & 28 & 1.71 & \\
\hline \multirow{2}{*}{ Aljufra (standard) } & 7 & 1.66 & \multirow{2}{*}{$11.11 \%$} \\
\hline & 28 & 2.83 & \\
\hline \multirow{2}{*}{ Aljufra (16\%) } & 7 & 1.64 & \multirow{2}{*}{$41.43 \%$} \\
\hline & 28 & 2.8 & \\
\hline \multirow[t]{2}{*}{ Aljufra $(32 \%)$} & 7 & 1.54 & \multirow{2}{*}{$4.94 \%$} \\
\hline & 28 & 1.62 & \\
\hline
\end{tabular}

Concrete as known is Weak tensile strength considered from the value of carrying concrete tensile strength of about $(8 \%)$ to $(12 \%)$ of compressive strength. through the recorded results turned out to be the value of the tensile strength of the samples containing the aggregate of AlJufrah volcanic higher than that contains the aggregate of Sirte Sedimentary. Also, the increase in the proportion of aggregates used in the concrete mix is inversely proportional to non-direct tensile resistance.

\section{References}

[1] A.S. Ngab, Libya-The construction industry-An overview, Karachi: CEDAW University of Engineering and Technology Karatchi Pakistan, (2007).

[2] A. Abdul Samad exclusively digital evaluation material quarries Libya, in: the Arab Conference Xi of mineral wealth, Tripoli, 2010.

[3] E. C 150, Standard Specification of Portland Cement, in, ASTM International West Conshohocken, PA, 2012. 
[4] B. 1881-116, Testing concrete. Method for determination of compressive Remove light stains of concrete cubes, in: initial submission Institution (ed.), London, UK, 1983.

[5] B. 1881-117, Testing concrete. Method for determination of tensile splitting Remove light stains, in: initial submission Institution (ed.), London, UK, 1983.

[6] E. C 128, Standard Test Method for Relative density (Specific Works) and absorption of Fine Aggregate, in, ASTM International, West Conshohocken, PA, 2015.

[7] E. C127, Standard Test Method for Relative density (Specific Works) and absorption of Coarse Aggregate, in, ASTM International West Conshohocken, PA, 2015.

[8] A.C. C131M, Standard Test Method for northern to Degradation of Small-Size Coarse Aggregate by Abrasion and impact in the Los Angeles MachineIn, ASTM International, West Conshohocken, PA, 2006.

[9] E. C535-12, Standard Test Method for northern to Degradation of Large-Size Coarse Aggregate by Abrasion and impact in the Los Angeles Machine, in, ASTM International West Conshohocken, PA, 2012.

[10] B. 812-112, Testing aggregates. Method for determination of aggregate impact value (AIV), in: initial submission Institution (ed.), London, UK, 1990.

[11] B. 812-103, Testing aggregates. Method for determination of particle size distribution. Sieve tests, in: initial submission Institution (ed.), London, UK, 1985.

\section{[Thanks]}

We want to extend our heartfelt thanks to the students by the following names for their great efforts for the success of this study:

- Mr. Abdul Wahab Mohammed.

- Mr. Mohamed Hamadi.

- Mr. Naim Abdul Nabi.

- Mr. Passem Aljalidy. 